archives-ouvertes

\title{
Study of WO3-decorated porous silicon and Al2O3-ALD encapsulation
}

\author{
R. Benabderrahmane Zaghouani, M. Alaya, H. Nouri, J.-L. Lazzari, W. \\ Dimassi
}

\section{To cite this version:}

R. Benabderrahmane Zaghouani, M. Alaya, H. Nouri, J.-L. Lazzari, W. Dimassi. Study of WO3decorated porous silicon and Al2O3-ALD encapsulation. Journal of Materials Science: Materials in Electronics, Springer Verlag, 2018, 29 (20), pp.17731-17736. 10.1007/s10854-018-9879-1 . hal01958616

\section{HAL Id: hal-01958616 https://hal.archives-ouvertes.fr/hal-01958616}

Submitted on 17 Feb 2021

HAL is a multi-disciplinary open access archive for the deposit and dissemination of scientific research documents, whether they are published or not. The documents may come from teaching and research institutions in France or abroad, or from public or private research centers.
L'archive ouverte pluridisciplinaire HAL, est destinée au dépôt et à la diffusion de documents scientifiques de niveau recherche, publiés ou non, émanant des établissements d'enseignement et de recherche français ou étrangers, des laboratoires publics ou privés. 


\title{
Study of $\mathrm{WO}_{3}$-decorated porous silicon and $\mathrm{Al}_{2} \mathrm{O}_{3}$-ALD encapsulation
}

\author{
R. Benabderrahmane Zaghouani ${ }^{1} \cdot$ M. Alaya ${ }^{1} \cdot$ H. Nouri ${ }^{1} \cdot$ J.-L. Lazzari ${ }^{2} \cdot$ W. Dimassi ${ }^{1}$
}

Received: 11 July 2018 / Accepted: 14 August 2018

\begin{abstract}
In this work, we report on the encapsulation of $\mathrm{WO}_{3}$-decorated porous silicon aluminum oxide $\left(\mathrm{Al}_{2} \mathrm{O}_{3}\right)$. Porous layers, elaborated for different current densities, are decorated by quasi-spherical $\mathrm{WO}_{3}$ nanoparticles with different densities and sizes. AFM analysis shows that the $\mathrm{WO}_{3}$ deposition is controlled by the prepared porous silicon morphology. $\mathrm{WO}_{3}$-treated porous silicon samples were faithfully coated by $\mathrm{ALD}-\mathrm{Al}_{2} \mathrm{O}_{3}$. A significant enhancement of porous silicon reflectance after $\mathrm{AL}_{2} \mathrm{O}_{3} /$ $\mathrm{WO}_{3}$ deposition was obtained. In order to quantify the passivation effect of the dual treatment, the effective diffusion length $\left(\mathrm{L}_{\text {eff }}\right.$ ) of the minority carriers is determined by Light Beam Induced Current (LBIC) measurements. An increase of $\mathrm{L}_{\text {eff }}$ from $74 \mu \mathrm{m}$ in porous silicon to $532 \mu \mathrm{m}$ in $\mathrm{AL}_{2} \mathrm{O}_{3} / \mathrm{WO}_{3} / \mathrm{PS}$ sample is reached. This enhancement is attributed to the dangling bonds saturation by alumina and tungsten oxide which leads to the diminution of the surface recombination velocities.
\end{abstract}

\section{Introduction}

Since its discovery [1], porous silicon (PS) is considered as an interesting material in different fields such as microelectronics, optical, photovoltaic, and sensing applications thanks to its properties: low surface reflection, high visible photoluminescence, and high internal surface [2-5]. To be integrated in solar cells, silicon nanostructures such as silicon nanowires [5] and PS, with their unstable surface in ambient conditions, should be passivated in order to ameliorate their optoelectronic properties. In particular, the minority carrier lifetime, a key parameter in silicon-based solar cells, is degraded in PS. In our previous work [6], we have reported on the passivation of PS, elaborated by stain-etching method, by tungsten oxide $\left(\mathrm{WO}_{3}\right)$. An enhancement of the photoluminescence of $\mathrm{WO}_{3}$-treated porous silicon $\left(\mathrm{WO}_{3} / \mathrm{PS}\right)$ is obtained. Moreover, the elaborated samples had a low surface reflectance up to about 5\%. An enhancement of the minority carrier lifetime was obtained thanks to surface recombination velocity decrease by saturating the dangling bonds by $\mathrm{WO}_{3}$. Obtained results have

R. Benabderrahmane Zaghouani rabia.benabderrahmane@gmail.com

1 Laboratoire de Photovoltaïque, Centre de Recherches et des Technologies de 1'Energie, Technopôle de Borj-Cédria, BP, 95 Hammam-Lif, Tunis, Tunisia

2 Aix Marseille Université, CNRS, CINaM UMR 7325, Campus de Luminy, Case 913, 163, Avenue de Luminy, 13288 Marseille Cedex 09, France confirmed that tungsten oxide is a good passivation layer to improve PS properties. In addition to that, the morphological results have shown that $\mathrm{WO}_{3}$ is deposited in the form of nanoparticles without covering the total surface of PS. To achieve a maximum of enhancement, the PS surface should be totally protected to reduce the surface recombination velocity. This could be achieved by depositing a passivating thin layer. In fact, the traditional passivation schemes used in photovoltaics are silicon dioxide $\left(\mathrm{SiO}_{2}\right)$, hydrogenated amorphous silicon nitride (a-SiNx:H) and hydrogenated amorphous silicon $(\mathrm{a}-\mathrm{Si}: \mathrm{H})[7,8]$. These materials provide good passivation levels but present some limits such as the low passivation of highly doped p-type silicon in the case of a-SiNx:H, the high processing temperature for the $\mathrm{SiO}_{2}$, the significant absorption in the visible and the thermal instability for the a-Si:H and the a-SiNx:H $[9,10]$. Many research reports have demonstrated that $\mathrm{Al}_{2} \mathrm{O}_{3}$ films provide an excellent passivation of both $\mathrm{n}$ and $\mathrm{p}$ type silicon [9] thanks to the combination of two mechanisms: the filed-effect passivation thanks to the presence of a high negative fixed charge density at the interface with silicon and the chemical passivation by reducing the interface state density. Another interesting issue is that $\mathrm{Al}_{2} \mathrm{O}_{3}$ has a large bandgap so it acts as an optical window leading to no significant absorption of the visible light which is very important in solar cells. Different deposition schemes are reported in the literature to obtain aluminum oxide such as pyrolysis [11], sol-gel [12], plasma enhanced chemical vapor deposition using the trimethyl aluminum (TMA) [13, 14], sputtering [15], atomic layer deposition (ALD) using TMA as a precursor [16]. 
Interestingly, the alumina thin films deposited by ALD could permit the uniform coating of nanostructures, in particular PS.

In this work, we report on the encapsulation of $\mathrm{WO}_{3} / \mathrm{PS}$ by alumina grown by $\mathrm{ALD}$. The $\mathrm{Al}_{2} \mathrm{O}_{3} / \mathrm{WO}_{3} / \mathrm{PS}$ structures performance is investigated by analyzing reflectance, current-voltage response and effective diffusion length measurement using the Light Beam Induced Current (LBIC) technique.

\section{Experimental techniques}

\subsection{Materials preparation}

PS samples were elaborated by electrochemical etching of polished $\mathrm{P}^{+}$type silicon wafer, (100) orientation, boron doped with a resistivity of $0.01-0.02 \Omega \mathrm{cm}$ and a thickness of $450 \mu \mathrm{m}$ in a mixture of hydrofluoric acid (40\%) and absolute ethanol in the volume ratio of (1:4) with different current densities $\left(5,10,15,20\right.$ and $\left.25 \mathrm{~mA} / \mathrm{cm}^{2}\right)$ during $10 \mathrm{~min}$. Before PS elaboration, silicon substrates were cleaned with boiling acetone for $10 \mathrm{~min}$, followed by immersion in ethanol for $5 \mathrm{~min}$ and rinsed after that in deionized water in order to eliminate organic greases. Finally, the substrates were etched in $10 \%$ hydrofluoric acid for $1 \mathrm{~min}$ to eliminate native oxide, rinsed in deionized water and dried with nitrogen flux. In order to obtain homogeneous PS films, an aluminum layer with a thickness of $300 \mathrm{~nm}$ was deposited on the back side of the silicon wafer by thermal evaporation followed by annealing under vacuum at $300{ }^{\circ} \mathrm{C}$ during $20 \mathrm{~min}$. After PS formation, the samples were dip-coated during $360 \mathrm{~s}$ in a solution of a concentration $0.018 \mathrm{~mol} / \mathrm{L}$ containing tungsten hexachloride $\left(\mathrm{WCl}_{6}\right)$ prepared previously in order to deposit $\mathrm{WO}_{3}$ layers [6, 17]. $\mathrm{WO}_{3} / \mathrm{PS}$ samples were then coated by aluminum oxide layer of a thickness of $50 \mathrm{~nm}$ grown by ALD technique using TMA and $\mathrm{H}_{2} \mathrm{O}$ as precursors at a temperature of $100^{\circ} \mathrm{C}$. The deposition parameters are listed in Table 1.

\subsection{Characterization tools}

The morphological features of the different prepared samples were characterized by a Digital Instruments Nanoscope III atomic force microscopy (AFM) operating in tapping mode and a scanning electron microscope (SEM) JEOL JSM-6340F. The optical properties of the samples based on the surface reflectance were analyzed using PerkinElmer Lambda 950 UV/VIS. The effect of the dual treatment $\left(\mathrm{Al}_{2} \mathrm{O}_{3} / \mathrm{WO}_{3}\right)$ on PS electrical properties is studied by LBIC measurements performed on a home-made set-up [18].

Table 1 ALD processing parameters

\begin{tabular}{llllll}
\hline ALD parameters & TMA & $\mathrm{N}_{2}$ & $\mathrm{H}_{2} \mathrm{O}$ & $\mathrm{N}_{2}$ & $\mathrm{~T}$ \\
\hline & $0.1 \mathrm{~s}$ & $3 \mathrm{~s}$ & $0.1 \mathrm{~s}$ & $4 \mathrm{~s}$ & $100{ }^{\circ} \mathrm{C}$ \\
\hline
\end{tabular}

\section{Results and discussion}

\subsection{Investigation of $\mathrm{WO}_{3}$ deposition by AFM}

PS samples are elaborated under different current densities during $10 \mathrm{~min}$. The porosity and the thickness of the etched layers are determined by gravimetric measurements and are presented in Fig. 1. Figure 2 shows the AFM images for $\mathrm{PS}$ and $\mathrm{WO}_{3} / \mathrm{PS}$ samples prepared for the different etching current densities. In order to deposit $\mathrm{WO}_{3}$, the different PS samples are immersed in the $\mathrm{WCl}_{6}$ solution for the same duration. As we can see, the PS surface for all samples is covered by quasi-spherical nanoparticles with different densities and sizes. This observation shows that the $\mathrm{WO}_{3}$ deposition is controlled by the prepared PS morphology. This result is confirmed by the RMS values recapitulated in Table 2. The PS measured RMS varies from 0.17 to $0.35 \mathrm{~nm}$. These low RMS values are attributed to the electrochemical etching technique used which offers a good surface homogeneity in the contrary to the stain etching technique [19]. After $\mathrm{WO}_{3}$ deposition, the RMS is changing from 0.54 to $9.58 \mathrm{~nm}$ for anodization current density of 5 and $25 \mathrm{~mA} / \mathrm{cm}^{2}$ respectively. Moreover, the ratio RMS (PS)/RMS $\left(\mathrm{WO}_{3} / \mathrm{PS}\right)$ is varying from 1.54 to 39.08 . All these observations confirm the control of the $\mathrm{WO}_{3}$ nanoparticles properties by modifying the PS parameters.

\subsection{Encapsulation of $\mathrm{WO}_{3} / \mathrm{PS}$ structures by $\mathrm{ALD}-\mathrm{Al}_{2} \mathrm{O}_{3}$}

As shown in [6], the tungsten oxide has improved the PS electronic and optical properties. A further amelioration of the deposited films properties can be reached by the deposition of alumina as it coats the total surface of the nanostructured surface. In particular, the reduction of the surface recombination velocity can be obtained. In addition to

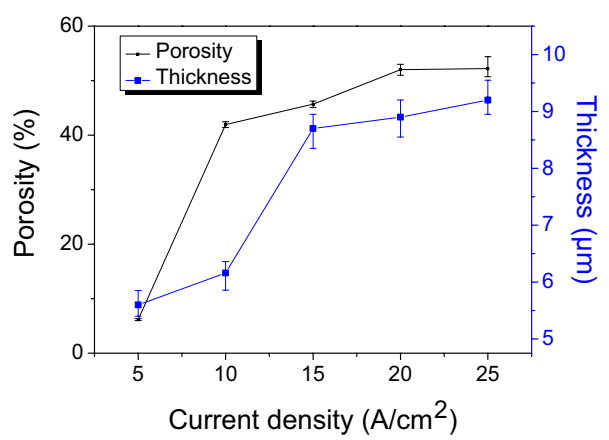

Fig. 1 The evolution of the PS porosity and thickness with the etching current density 
that, alumina can protect these structures from atmospheric degradation.

Figure 3 shows the top-view SEM image of the PS surface elaborated with a current density of $20 \mathrm{~mA} / \mathrm{cm}^{2}$. The pores, perfectly circular, are uniformly formed on the surface. After immersion in the prepared $\mathrm{WCl}_{6}$ solution during $360 \mathrm{~s}$, PS surface was covered with quasi-spherical $\mathrm{WO}_{3}$ nanoparticles (Fig. 4). The formed nanostructures have an average size of $60 \mathrm{~nm}$. Then, $\mathrm{Al}_{2} \mathrm{O}_{3}$ layer with $50 \mathrm{~nm}$ of thickness is deposited on $\mathrm{WO}_{3} / \mathrm{PS}$ sample (Fig. 5). As shown in Fig. 5, the $\mathrm{WO}_{3}$ nanoparticles are faithfully coated with alumina. The roughness evolution with the different treatments is determined by AFM micrographs of $\mathrm{PS}, \mathrm{WO}_{3} / \mathrm{PS}$ and $\mathrm{Al}_{2} \mathrm{O}_{3} / \mathrm{WO}_{3} / \mathrm{PS}$ samples. After $\mathrm{WO}_{3}$ deposition, the RMS is increased from $0.24 \mathrm{~nm}$ for PS sample to $9.38 \mathrm{~nm}$ for $\mathrm{WO}_{3} / \mathrm{PS}$ and when depositing aluminum oxide, the RMS is decreased to about $6 \mathrm{~nm}$ due to the pores filling by alumina.

\subsection{Surface reflectance analysis}

PS is considered as an efficient antireflection layer that could be integrated in photovoltaic applications thanks to the light-trapping into the pores. The elaborated structures based on PS should keep or better ameliorate the antireflection aspect of the porous layer. In Fig. 6, we compare the surface reflectance of PS and $\mathrm{Al}_{2} \mathrm{O}_{3} / \mathrm{WO}_{3} / \mathrm{PS}$ samples. The spectra show a significant enhancement of PS reflectance after the different treatments. The reflectance decreases from about $25 \%$ for PS sample to about $12 \%$ for $\mathrm{Al}_{2} \mathrm{O}_{3} / \mathrm{WO}_{3} / \mathrm{PS}$ sample in the visible region. This result is attributed to the combined effect of both $\mathrm{WO}_{3}$ nanostructures and aluminum oxide. As demonstrated in [6], the $\mathrm{WO}_{3}$ integration leads to PS reflectance decrease. The obtained low reflectance, in particular around the visible region of the solar spectrum, is encouraging the integration of these structures in an efficient photovoltaic device.

\subsection{Current-voltage analysis}

To investigate the efficiency of the different treatment, current-voltage analysis was carried on. Figure 7 shows the $\mathrm{I}-\mathrm{V}$ characteristic of the elaborated diodes, Al/PS and Al/ $\mathrm{Al}_{2} \mathrm{O}_{3} / \mathrm{WO}_{3} / \mathrm{PS}$, measured at room temperature under dark conditions. After PS treatment with tungsten oxide and alumina, an increase in the current is obtained. Moreover, the threshold voltage from which a noticeable current increase is shifted to lower value in the case of the $\mathrm{Al} / \mathrm{Al}_{2} \mathrm{O}_{3} / \mathrm{WO}_{3} / \mathrm{PS}$ diode attributed to the conduction amelioration.

\subsection{LBIC analysis}

The formation mechanism of PS leads to H-terminated surface which is unstable in ambient conditions. Due to the appearance of dangling bonds on PS surface the effective minority carrier lifetime $\left(\tau_{\text {eff }}\right)$ is deteriorated. In fact, $\tau_{\text {eff }}$ takes into account the lifetime in the bulk and at the surface as depicted in Eq. (1).

$\frac{1}{\tau_{\text {eff }}}=\frac{1}{\tau_{\text {bulk }}}+\frac{1}{\tau_{\text {surface }}}$

The surface lifetime, related to the surface recombination velocity, could be ameliorated by passivating the surface leading to the enhancement of the effective diffusion length $\left(\mathrm{L}_{\text {eff }}\right)$ which is related to $\tau_{\text {eff }}$ by the following equation:

$L_{e f f}=\sqrt{D \times \tau_{\text {eff }}}$

where $\mathrm{D}$ is the diffusion coefficient.

$\mathrm{L}_{\text {eff }}$ gives an evaluation of the quality of the structure as it depends on the bulk diffusion length $\left(\mathrm{L}_{\mathrm{b}}\right)$ and the effective surface recombination velocities $\left(\mathrm{S}_{\mathrm{eff}}\right)$.

As mentioned above, in our previous work [6], the PS surface coating by $\mathrm{WO}_{3}$ has ameliorated the effective minority carrier lifetime by decreasing the surface recombination velocity which could be enhanced by alumina coating. In order to quantify the effect of the $\mathrm{Al}_{2} \mathrm{O}_{3}$ encapsulation on the electronic properties of the $\mathrm{WO}_{3} / \mathrm{PS}$, the diffusion length of the minority carriers is determined by LBIC measurements. LBIC is based on the scanning of the sample surface by a light beam leading to the creation of electron-holes pairs. The collected current is depending $\mathrm{L}_{\text {eff }}$ which is affected by the scanned surface quality. In our experiment, the laser diode with a wavelength $\lambda=632 \mathrm{~nm}$ is focused perpendicular to the sample surface leading to a penetration depth around $3 \mu \mathrm{m}$ in silicon. The carrier's generation is then occurring in the PS. Figure 8 presents the measured current $\mathrm{I}_{\text {LBIC }}$ as a function of the beam position ( $\mathrm{x}$ ) for the $\mathrm{Al}_{2} \mathrm{O}_{3} / \mathrm{WO}_{3} / \mathrm{PS}$ sample and the untreated PS. In order to determine $\mathrm{L}_{\text {diff }}$, the current decay is fitted using the following theoretical expression Eq. (3) [20]:

$I \alpha \exp \left(-\frac{x}{L_{e f f}}\right)+I_{0}$

An effective diffusion length of $74 \mu \mathrm{m}$ is obtained for the PS sample. The coating of the PS sample by $\mathrm{Al}_{2} \mathrm{O}_{3} /$ $\mathrm{WO}_{3}$ layers has increased the diffusion length to about $532 \mu \mathrm{m}$. This enhancement is attributed to the dangling bonds saturation by alumina and tungsten oxide which leads to the diminution of the surface recombination velocities. This result is confirming the passivation effectiveness of $\mathrm{PS}$ by the $\mathrm{Al}_{2} \mathrm{O}_{3} / \mathrm{WO}_{3}$ dual treatment. 

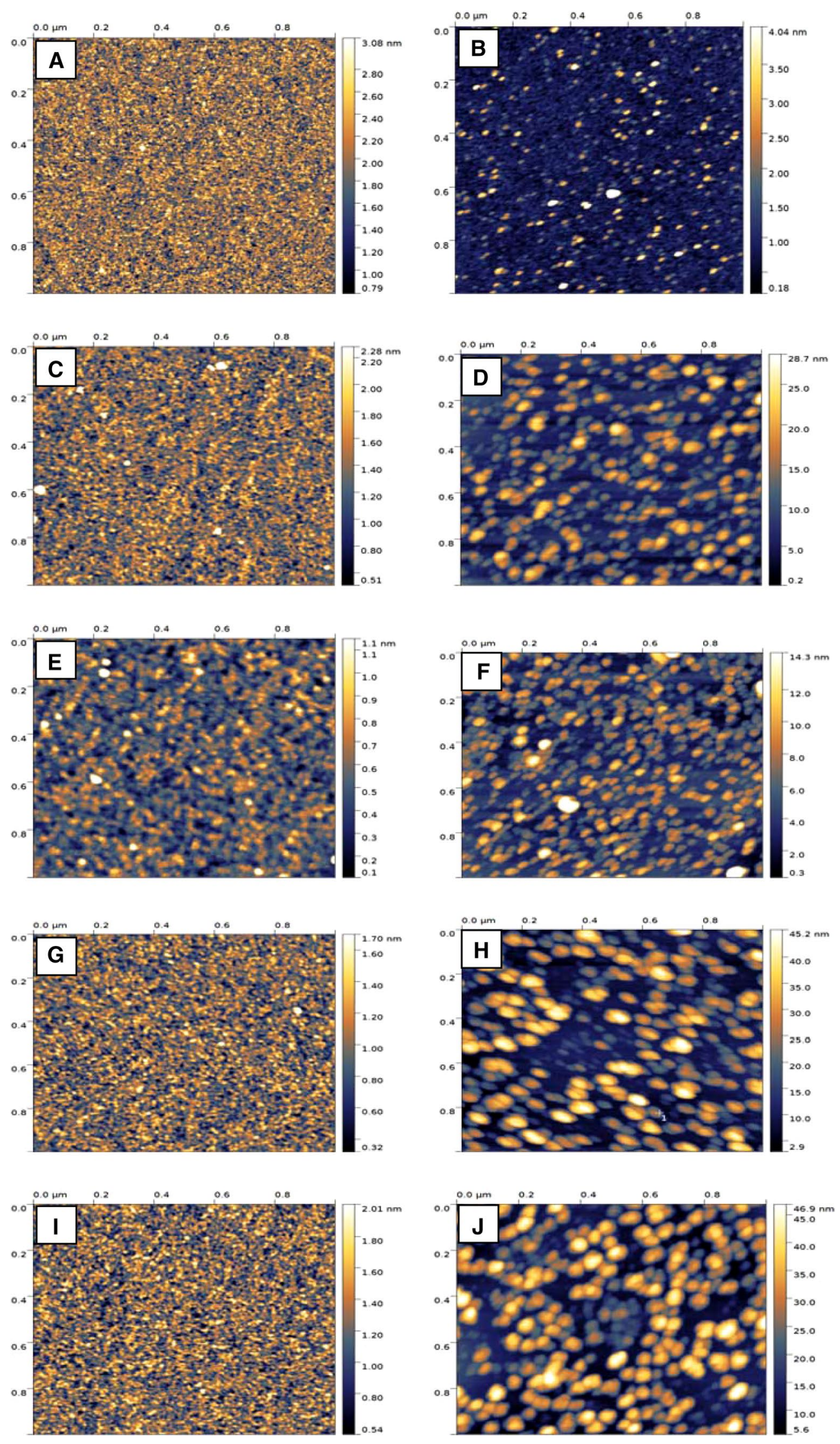
4 Fig. 2 AFM images of PS and $\mathrm{WO}_{3} / \mathrm{PS}$ samples elaborated at different etching current densities: a, b $5 \mathrm{~mA} / \mathrm{cm}^{2}$, c, d $10 \mathrm{~mA} / \mathrm{cm}^{2}$, e, f $15 \mathrm{~mA} / \mathrm{cm}^{2}, \mathbf{g}, \mathbf{h ~} 20 \mathrm{~mA} / \mathrm{cm}^{2}, \mathbf{i}, \mathbf{j} 25 \mathrm{~mA} / \mathrm{cm}^{2}$

Table 2 Measured RMS for PS and $\mathrm{WO}_{3} / \mathrm{PS}$ for different electrochemical etching current density

\begin{tabular}{llllrr}
\hline Current density $\left(\mathrm{mA} / \mathrm{cm}^{2}\right)$ & \multicolumn{1}{l}{10} & \multicolumn{1}{l}{15} & \multicolumn{1}{l}{20} & \multicolumn{1}{c}{25} \\
\hline RMS (PS) (nm) & 0.35 & 0.33 & 0.17 & 0.24 & 0.28 \\
RMS (WO $/ \mathrm{PS})(\mathrm{nm})$ & 0.54 & 4.66 & 2.49 & 9.38 & 9.58 \\
RMS (PS)/RMS (WO $/ \mathrm{PS})$ & 1.54 & 14.12 & 14.64 & 39.08 & 34.21 \\
\hline
\end{tabular}

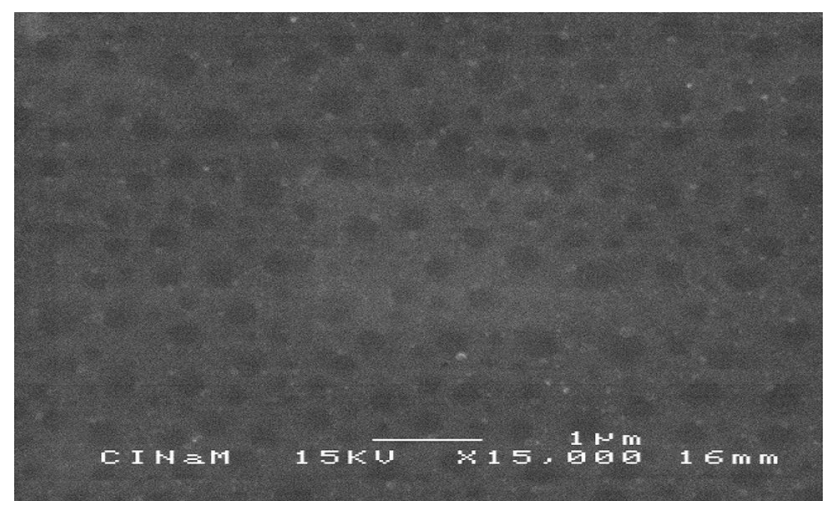

Fig. 3 Top surface SEM view of PS surface

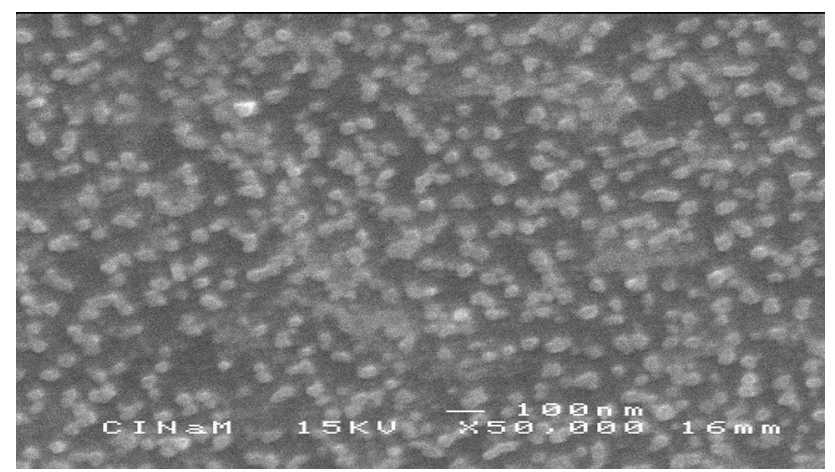

Fig. 4 Top surface SEM view of PS surface covered with $\mathrm{WO}_{3}$ nanoparticles

\section{Conclusion}

In this study, we have evaluated the effects of tungsten oxide and alumina treatment on PS optoelectronic properties. AFM confirmed the total coverage of PS surface by $\mathrm{WO}_{3}$ nanostructured thin film. The density and the size of the deposited $\mathrm{WO}_{3}$ nanoparticles are controlled by the PS morphology. These structures are faithfully coated by an encapsulation by $\mathrm{Al}_{2} \mathrm{O}_{3}$ layer. We have demonstrated that the

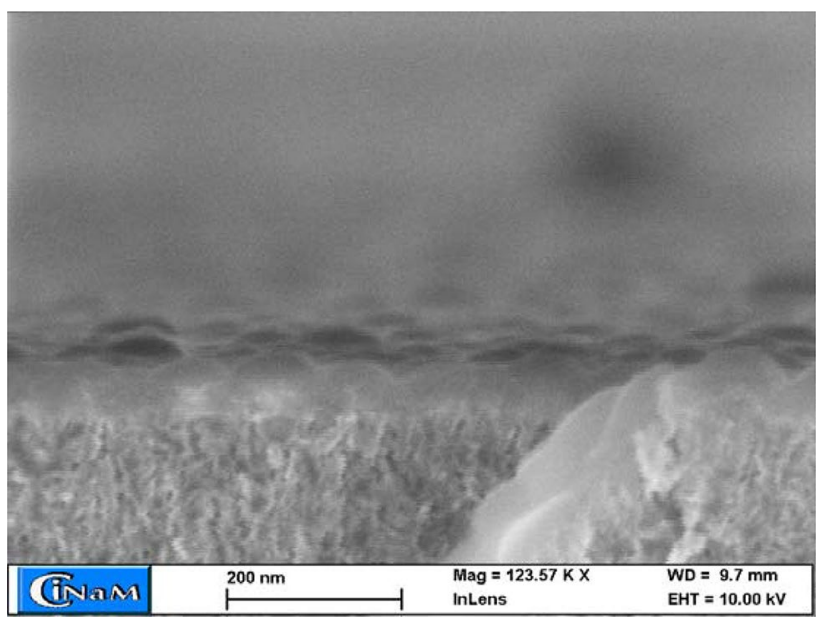

Fig. 5 Cross-section SEM image of $\mathrm{Al}_{2} \mathrm{O}_{3} / \mathrm{WO}_{3} / \mathrm{PS}$ sample

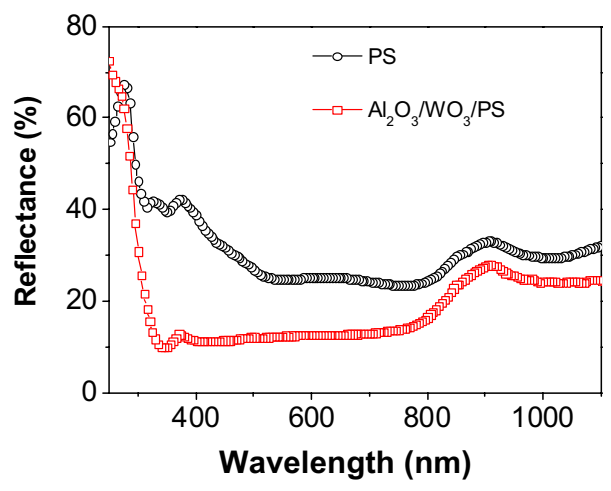

Fig. 6 Reflectance spectra of $\mathrm{PS}$ and $\mathrm{Al}_{2} \mathrm{O}_{3} / \mathrm{WO}_{3} / \mathrm{PS}$ samples

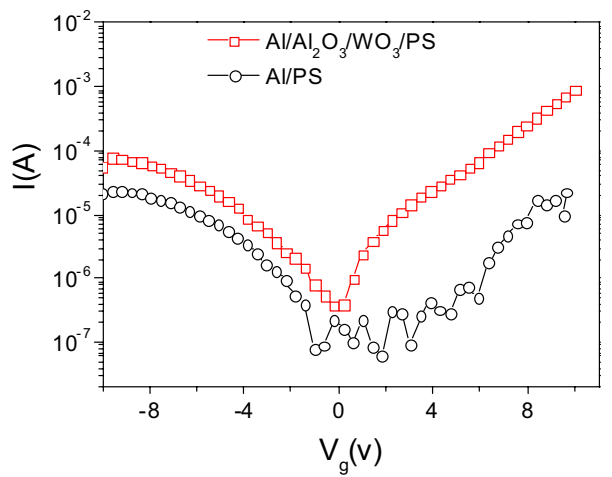

Fig. 7 Current versus applied voltage $\mathrm{Vg}$ for $\mathrm{Al} / \mathrm{PS}$ and $\mathrm{Al} / \mathrm{Al}_{2} \mathrm{O}_{3} /$ $\mathrm{WO}_{3} / \mathrm{PS}$ diodes

dual treatment $\mathrm{Al}_{2} \mathrm{O}_{3} / \mathrm{WO}_{3}$ has improved the PS reflectance. Moreover, the PS passivation is confirmed by the enhancement of the minority carrier diffusion length which increases from $74 \mu \mathrm{m}$ for the untreated sample to $532 \mu \mathrm{m}$ for the 


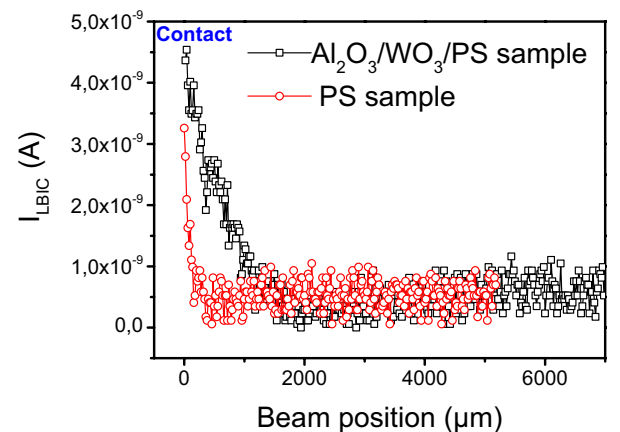

Fig. 8 Experimental LBIC profiles for PS and $\mathrm{Al}_{2} \mathrm{O}_{3} / \mathrm{WO}_{3} / \mathrm{PS}$ samples

treated one. These interesting results encourage the integration of these structures in different optoelectronic devices.

Acknowledgements The authors wish to thank Alain Ranguis and Damien Chaudanson for AFM and SEM measurements done at the Centre Interdisciplinaire de Nanoscience de Marseille (CINaM).

\section{References}

1. L.T. Canham, Appl. Phys. Lett. 57, 1046 (1990)

2. R.T. Collins, P.M. Fauchet, M.A. Tischler, Phys. Today 50, 24 (1997)

3. A. Richter, P. Steiner, F. Kozlowski, W. Lang, IEEE Electron Devices Lett. 12, 691 (1991)
4. M. Rajabi, R.S. Dariani, J Porous Mater. 16, 513 (2009)

5. M.Y. Tabassi, R.B. Zaghouani, M. Khelil, K. Khirouni, W. Dimassi, J. Mater. Sci.: Mater. Electron. 28, 9717 (2017)

6. M. Alaya, R.B. Zaghouani, S. Khamlich, J.L. Lazzari, W. Dimassi, Thin Solid Films 645, 51 (2018)

7. A.G. Aberle, Sol. Energy Mater. Sol. Cells 65, 239 (2001)

8. S. Dauwe, J. Schmidt, R. Hezel, In 29th IEEE Photovoltaic Specialists Conference, New Orleans (2002)

9. B. Hoex, S.B.S. Heil, E. Langereis, M.C.M. Van de Sanden, W.M.M. Kessels, Appl. Phys. Lett. 89, 042112 (2006)

10. S. Dauwe, L. Mittelstädt, A. Metz, R. Hezel, Prog. Photovolt. Res. Appl. 10, 271 (2002)

11. R. Hezel, K. Jaeger, J. Electrochem. Soc. 136, 518 (1989)

12. P. Vitanov, A. Harizanova, T. Ivanova, T. Dimitrova, Thin Solid Films 517, 6327 (2009)

13. G. Dingemans, M.C.M. Van de Sanden, W.M.M. Kessels, Electrochem. Solid-State Lett. 13, H76 (2010)

14. P. Saint-Cast, J. Benick, D. Kania, L. Weiss, M. Hofmann, J. Rentsch, R. Preu, S.W. Glunz, IEEE Electron Device Lett. 31, 695 (2010)

15. T.T. Li, A. Cuevas, Phys. Status Solidi (RRL)-Rapid Res. Lett. 3, 160 (2009)

16. G. Dingemans, N.M. Terlinden, D. Pierreux, H.B. Profijt, M.C.M. Van de Sanden, W.M.M. Kessels, Electrochem. Solid-State Lett. 14, H1 (2011)

17. S. Badilescu, P.V. Ashrit, Solid State Ion. 158, 187 (2002)

18. M.B. Rabha, W. Dimassi, M. Bouaïcha, H. Ezzaouia, B. Bessais, Sol. Energy 83, 721 (2009)

19. M.B. Rabha, M. Salem, M.A. El Khakani, B. Bessais, M. Gaidi, Mater. Sci. Eng. B 178, 695 (2013)

20. Y. Sayad, A. Kaminski, D. Blanc, A. Nouiri, M. Lemiti, Superlatt. Microstruct. 45, 393 (2009) 